The reaction was not uniform throughout the liver, being more marked in the periphery of the lobule, the centre being comparatively free. The precipitate was always in the cytoplasm of the cell ; the nucleus did not show any reaction and was unstained. Octyl alcohol completely inhibited the reaction, no blue colour being visible anywhere in the tissue. Potassium cyanide had no effect on the reaction.

Physiological Laboratory,

$$
\text { C. M. Francis }
$$

University, Cambridge. Jan. 21.

' Dianzani, M. U., Nature, 171, 125 (1953).

${ }^{2}$ Richter, 1., Biochem. J., 31, 2022 (1937).

shilpot, F. J., Biochem. J., 31, 856 (1937).

4 Shelton, E., and Schneider, W. C., Anat. Rec., 112, 61 (1952).

"Blaschko, H., Richter, D., and Schlossmann, H., Biochem. J., 3I, 2187 (1937).

\section{Lactate-oxidizing Systems in the Mycobacteria}

IN a recent communication, $Y$. Yamamura, $M$. Kusunose and E. Kusunose ${ }^{1}$ described two "lactic oxidases" prepared from Mycobacterium avium. "Lactic oxidase I" is said to be a new type of lactateoxidizing system which catalyses the reaction:

$\mathrm{CH}_{3} \cdot \mathrm{CHOH} . \mathrm{COOH}+\mathrm{O}_{2} \rightarrow \mathrm{CH}_{3} \cdot \mathrm{COOH}+\mathrm{CO}_{2}+\mathrm{H}_{2} \mathrm{O}$.

The authors are apparently unaware that a soluble aerobic dehydrogenase catalysing the same oxidation of L-lactate was extracted from Mycobacterium phlei several years ago ${ }^{2}$. Preparations of a similar, if not identical, enzyme have been obtained from $M y c o-$ bacterium smegmatis and Mycobacterium tuberculosis var. hominis (H37 strain) $)^{3}$. For these and other reasons, it was suggested that L-lactic acid oxidase is an enzyme common to all species of acid-fast bacteria ${ }^{4}$.

One of the hypotheses originally put forward to explain reaction (1) postulated three consecutive steps $^{2}$ :

$$
\begin{aligned}
& \mathrm{CH}_{3} . \mathrm{CHOH} . \mathrm{COOH}+F=\mathrm{FH}_{2}+\mathrm{CH}_{3} \cdot \mathrm{CO} . \mathrm{COOH}(2) \\
& F^{2} \mathrm{H}_{2}+\mathrm{O}_{2}=F+\mathrm{H}_{2} \mathrm{O}_{2} \\
& \mathrm{CH}_{3} \cdot \mathrm{CO} \cdot \mathrm{COOH}+\mathrm{H}_{2} \mathrm{O}_{2}=\mathrm{CH}_{3} \cdot \mathrm{COOH}+\mathrm{CO}_{2}+ \\
& \mathrm{H}_{2} \mathrm{O} \text { (non-enzymic) }
\end{aligned}
$$

In this scheme, $F$ was assumed to be an autoxidizable flavoprotein containing flavin-adenine-dirucleotide because this class of protein was found in the enzyme preparations ; but it was pointed out that the hypothesis could not be tested satisfactorily until purer preparations became available ${ }^{2,4}$. Yamamura et al. have likewise assumed that "lactic oxidase $I$ " is a flavoprotein with flavin-adenine-dinucleotide as its prosthetic group.

Our assumption identifying the lactic enzyme with a flavoprotein has proved to be false. Using large quantities of bacteria, one of us (F. B. C.) has achieved a considerable purification of the L-lactateoxidizing enzymes extractable from Mycobact. phlei, Mycobact. smegmatis and Mycobact. stercoris. These preparations exhibit identical enzymic behaviour. Flavins (free and combined) are removed during the purification, details of which will be published elsewhere. The most active preparation from Mycobact. smegmatis has $Q_{\mathrm{O}_{2}}$ (per mgm. nitrogen) $=166,000$ at the optimum $p \mathrm{FL}(5 \cdot 2)$ and at $38^{\circ}$. This is sixty times as active as the best preparation of Yamamura et al.

Concentrated solutions of partially purified enzyme are orange-yellow in colour and exhibit three electrophoretic components, one of which contains the enzyme. The pigment migrates with the enzyme. The absorption spectrum shows typical protein bands in the ultra-violet region with additional absorption at $380-403 \mathrm{~m} \mu$ due to the pigment. It is possible that the pigment is a prosthetic group of the enzyme, but this is unlikely since the pigment is removed progressively as the enzyme is purified.

Mechanism of reaction. Yamamura et al. consider that their experiments exclude the possibility of formation of hydrogen peroxide. The evidence seems to be that oxygen consumption and carbon dioxide production in reaction (1) are unaffected by addition of catalase or catalase plus ethanol. This evidence shows $(a)$ that catalase does not inhibit the oxidation of lactate, and $(b)$ that coupled oxidation does not occur in the presence of ethanol and catalase (carbon dioxide production unaltered). Though significant, this evidence is not conclusive. If pyruvate and hydrogen peroxide react spontaneously on the enzyme surface where they originate, there may be limited diffusion of hydrogen peroxide to an indicator system.

Our purified enzyme preparations behave in a similar way with catalase. Nevertheless, the experiment illustrated in the accompanying table supports the view that hydrogen peroxide is formed in accordance with reactions (2) and (3). The experiment employs horseradish peroxidase and $p$-aminobenzoic acid as a means of detecting hydrogen peroxide ${ }^{5}$. In the presence of peroxidase, $p$-aminobenzoic acid is oxidized only when lactate is oxidized simultaneously; in the absence of peroxidase there is no coupling.

Detection of Hydrogen Peroxide DURING the Oxidation of

\begin{tabular}{|l|c|c|}
\hline \multicolumn{1}{|c|}{ I.ACTATE } \\
\hline \multicolumn{1}{|c|}{ Additions } & $\begin{array}{c}\text { Oxygen uptake } \\
(\mu / 60 \text { min. })\end{array}$ & $\begin{array}{c}\text { Dye } \\
\text { formation }\end{array}$ \\
\hline $\begin{array}{l}\text { Nil } \\
p \text {-Aminobenzoic acid + per- } \\
\text { oxidase }\end{array}$ & 0 & Nil \\
Lactate & 0 & Nil \\
Lactate + $p$-aminobenzoic acid & 381 & Nil \\
Lactate + peroxidase & 394 & Nil \\
actate +p-aminobenzoic & 345 & Red \\
Pyruvate + peroxidase & 384 & Nil \\
acid + peroxidase & 0 & \\
\hline
\end{tabular}

Warburg manometric cups contained : $0.2 \mathrm{ml}$. enzyme solution (L-lactic acid oxidase from Mycobact. smegmatis) and $0.9 \mathrm{ml} .0 .2 M$ acetate buffer, $p H 5 \cdot 2$. Gas, air. Temp., 38 . Inseal, $0.2 \mathrm{ml} .2 \mathrm{~N}$
sodium hydroxide. Additions : $1.0 \mathrm{M}$. 2 -lactate $(0.5 \mathrm{ml}): 0.2 \mathrm{M}$ sodium hydroxide. Additions : $1.0 M$ DL-lactate $(0.5 \mathrm{ml}) ; 0.2 M$
pyruvate $(0.5 \mathrm{ml}) ;$ peroxidase solution $(0.2 \mathrm{ml}) ; 0.025 M p$ aminobenzic acid (0.2 ml.); water to make total volume, $2 \mathrm{ml}$. in each case.

We have not encountered a DPN-linked anaerobic dehydrogenase like "lactic oxidase II" in the organisms we have studied.

N. L. EDson

F. B. Cousins

Travis Laboratory, Department of Biochemistry,

University of Otago Medical School, New Zealand. Oct. 15.

${ }^{1}$ Yamarnura, Y., Kusunose, M., and Kusunose, E., Nature, 170, 207 $(1952)$.

${ }^{2}$ Edson, N. L., Biochem. J., 41, 145 (1947).

${ }^{3}$ Geronimus, I. H., Gray, C. T., and Birkeland, J. M., Abstracts of Papers, Soc. Amer. Bacteriologists, 49th General Meeting, 42 (1949).

${ }^{4}$ Edson, N. L., Ract. Rev., 15, 165 (1951).

${ }^{5}$ Lipmann, H., $J$. Biol. Chem., 139, 977 (1941). 